\title{
Intraspecific variation and geographic patterns of Fagus orientalis Lipsky chloroplast DNA
}

\author{
By P. Salehi Shanjani ${ }^{1}$, C. Vettori ${ }^{2}$, R. Giannini ${ }^{2}$ and R. A. Khavari-NejaD ${ }^{3}$
}

(Received 21 $1^{\text {st }}$ May 2003)

\begin{abstract}
CpDNA variation in Iranian beech, Fagus orientalis Lipsky (Fagaceae) was studied in 14 populations distributed throughout the species range in the Hyrcanain zone. Two cpDNA intergenic regions were analyzed: (i) one in the DT region between trn $\mathrm{D}$ (tRNA-Asp) and $\operatorname{trn} \mathrm{T}$ (tRNA-Thr) genes, and (ii) one in the OA region between the orf 184 and pet $\mathrm{A}$ genes. The restriction fragments of the region DT did not show polymorphism among individuals within any population analyzed. However, among individuals within analyzed populations of Asalem region and Neka-1400 population, polymorphism in the restriction fragments of the OA region were found. A total of 3 different chloroplast (cp) haplotypes were scored. The distribution of the cpDNA haplotypes revealed a geographical structure of the genetic differentiation with Gst $=\% 68.7$ and Nst $=\% 70.3$. The distribution pattern of $F$. orientalis cpDNA haplotypes may reflect environmental differences and migration history of beech during historical distribution in Tertiary from Asalem (most polymorphic region) to East of Hyrcanian forests.
\end{abstract}

Key words: cpDNA, Fagus orientalis Lipsky, Hyrcanian zone, Iranian beech, intraspecific diversity, genetic patterns.

\section{Introduction}

Chloroplast DNA (cpDNA) is highly conserved and has a lower mutation rate than sequences present in the plant nuclear genome (WOLFE et al., 1987). This can be a serious limitation for studies at low taxonomic levels. Despite the conservative nature of cpDNA evolution, restriction site and length variation has been detected within many species. (SolTis et al., 1989, 1991, 1992; ARNOLD et al., 1991; BYRne and Moran, 1994).

Intraspecific phylogeography, defined by Avise et al. (1987) as the study of the relationship between the phylogeny of variants and their geographic distribution, is more and more becoming of interest in evolutionary science (DUMOLIN-LAPÈGUE et al., 1997). Intraspecific cpDNA variation has also facilitated studies of population-level phenomena, such as gene flow, longdistance seed dispersal, and genetic diversity within and among populations. These processes bear directly on the interpretation of cpDNA evolution with regard to phylogenetic studies (Soltis et al., 1992).

Several studies of geographical variation in the Fagaceae family have been done using molecular markers of cpDNA (Dumolin-LAPÈGue et al., 1997, 1998; TARBELET et al., 1998; WhitTEMORE and SCHAAL, 1991). DEMESURE et al. (1996) studied the polymorphism in the chloroplast genome of European beech

\footnotetext{
1) Dr. Parvin Salehi Shanjani, Member of scientific board at Forest Research Division Research Institute of Forests and Rangelands, P.O. Box 13185-116, Tehran, Iran. Tel.: 009821419 5901, 5902, 5903, 5904, 5905. Fax: 009821419 6575, 6571. E-mail: psalehi@rifr-ac.ir and psalehi2@yahoo.com. http://www.rifr-ac.org/research_divisions/ forest/salehi.htm

2) Institute of Plant Genetic, CNR, via Madonna del Piano, I-50019 Sesto Fiorentino, Firenze. Italy.

$\left.{ }^{3}\right)$ Biology Department, Faculty of Science, University of Teachers Education, Tehran, Iran.
}

(Fagus sylvatica L.) by relative restriction site studies of PCRamplified fragments. In a large survey (399 individuals in 85 populations), they found eleven haplotypes, which could be phylogenetically ordered, encompassing most of the natural range of the species. According to their results the northern most populations of Europe are genetically uniform, suggesting a bottleneck at the time of postglacial recolonisation, a scenario which fits with paleobotanical reconstructions. They infer a correlation between geographic distribution of cpDNA haplotypes and their phylogenetic relationships.

Among the broad-leaved temperate forests on Northern Hemisphere, Hyrcanian forest types are very special. These forests with total area of 1.5 million ha are located at southern costs of Caspian Sea and on the northern slopes of Alborz Mountain in the northern part of Iran. The Hyrcanian forest ecosystem is considered to be one of the last remnants of natural deciduous forests in the world. In comparison to European broad-leaved forests from Paleobotanical point of view, which has been influenced by the glacial and human activities, the Hyrcanian forests seem to have remained from the Tertiary and to be relic ecosystem (Sagheb-Talebi, 2000). The watershed of the Alborz on the Caspian coast is characterized by mesophilous forest vegetation, originating from the Tertiary, therefore being very ancient. Beech in this zone survived intense climate and geological changes during the Quaternary because the populations lived in this area were not in contact with glacial periods, but influenced indirectly (MOBAYEN and Tregubov, 1969). From the point of view of its floristic composition, the beech belt is linked with European forests. This level particularly has some affinities with the beech forests of the Balkans. The lower levels, on the contrary, are much more specific and include subtropical elements.

Pure and mixed beech (Fagus orientalis Lipsky) forests are the most important, making up the richest and the most beautiful forests of Iran containing trees up to $50 \mathrm{~m}$ hight and $2 \mathrm{~m}$ in diameter. From the economical point of view, they are the most important and commercial forests in the Caspian zone. Beech forests cover around $17.6 \%$ of Hyrcanian forests surface and form around $25 \%$ of forest trees volume in Iran. Therefore, from the economical point of view, beech stands are the most valuable stands and allocate the most rate of timber production in Iran.

It is the objective of our study to better understand genetic diversity and phylogenetical relations of oriental beech populations.

\section{Material and Methods \\ Population characteristics and sampling}

The studied beech forests are located on the northern slopes of Alborz Mountains, within an altitude of about 600-2000 m above sea level. They have formed a forest strip with $600 \mathrm{~km}$ length that is located in 3 provinces of Gilan, Mazandaran and Golestan. We sampled a total of 72 trees from 14 autochthonous beech populations representing the entire geographical range of Fagus orientalis in Iran (Table 1, Fig. 1). 
Table 1. - Site characteristics of the studied populations of Fagus orientalis.

\begin{tabular}{|c|c|c|c|c|c|c|c|}
\hline Region & $\begin{array}{c}\text { Altitude } \\
\text { (m) }\end{array}$ & Abbreviation & $\begin{array}{c}\text { Latitude } \\
\text { (N) }\end{array}$ & $\begin{array}{l}\text { Longitude } \\
\text { (E) }\end{array}$ & Exposition & Forest composition & $\begin{array}{c}\text { Canopy } \\
(\%)\end{array}$ \\
\hline Gorgan & 2000 & G-2000 & $36^{\prime} 45^{\prime \prime}$ & $54^{\prime} 07^{\prime \prime}$ & $\mathrm{N}, \mathrm{NW}$ & Beech $90 \%$ & 95 \\
\hline “ & 1400 & $G-1400$ & $36^{\prime} 41^{\prime \prime}$ & $54^{\prime} 05^{\prime \prime}$ & $\mathrm{N}, \mathrm{NW}$ & Beech $90 \%$ & 90 \\
\hline “ & 600 & G-600 & $36^{\prime} 42^{\prime \prime}$ & $54^{\prime} 06^{\prime \prime}$ & $\mathrm{N}, \mathrm{NW}$ & Beech $90 \%$ & 90 \\
\hline Neka & 1400 & $N-1400$ & $36^{\prime} 22^{\prime \prime}$ & $53^{\prime} 33^{\prime \prime}$ & $\mathrm{N}, \mathrm{NW}$ & Beech $90 \%$ & 80 \\
\hline “ & 900 & N-900 & $36^{\prime} 29^{\prime \prime}$ & $53^{\prime} 27^{\prime \prime}$ & $\mathrm{N}, \mathrm{NW}$ & Beech $90 \%$ & 90 \\
\hline Sangdeh & 1900 & S-1900 & $36^{\prime} 00^{\prime \prime}$ & $53^{\prime} 12^{\prime \prime}$ & $\mathrm{N}, \mathrm{NW}$ & Beech $90 \%$ & 95 \\
\hline “ & 1400 & $S-1400$ & $36^{\prime} 03^{\prime \prime}$ & $53^{\prime} 14^{\prime \prime}$ & SW, W & Beech $70 \%$ & 70 \\
\hline “ & 900 & S-900 & $36^{\prime} 06^{\prime \prime}$ & $53^{\prime} 16^{\prime \prime}$ & $\mathrm{N}, \mathrm{NW}$ & Beech $90 \%$ & 65 \\
\hline Kheirud & 2000 & K-2000 & $36^{\prime} 28^{\prime \prime}$ & $5 I^{\prime} 40^{\prime \prime}$ & $\mathrm{N}$ & Beech $90 \%$ & 90 \\
\hline “ & 1200 & $\mathrm{~K}-1200$ & $36^{\prime} 32^{\prime \prime}$ & $51^{\prime} 39^{\prime \prime}$ & $\mathrm{SE}$ & Beech $90 \%$ & 90 \\
\hline “ & 600 & $\mathrm{~K}-600$ & $36^{\prime} 35^{\prime \prime}$ & $51^{\prime} 33^{\prime \prime}$ & SE & Beech $90 \%$ & 90 \\
\hline Asalem & 1900 & A- 1900 & $37^{\prime} 38^{\prime \prime}$ & $48^{\prime} 46^{\prime \prime}$ & $\mathrm{N}$ & Beech $90 \%$ & 80 \\
\hline “ & 1200 & A- 1200 & $37^{\prime} 38^{\prime \prime}$ & $48^{\prime} 48^{\prime \prime}$ & NW & Beech $90 \%$ & 90 \\
\hline “ & 600 & A- 600 & $37^{\prime} 41^{\prime \prime}$ & $48^{\prime} 48^{\prime \prime}$ & $\mathrm{N}$ & Beech $90 \%$ & 70 \\
\hline
\end{tabular}

\section{Laboratory analysis}

DNA was isolated from dormant buds (100 mg as starting material) using Nucleospin plant kit (Macherey Nagel, Germany).

The intergenic spacers between the $\operatorname{trn} \mathrm{D}$ (tRNA-Asp)-trn T (tRNA-Thr) and orf184-petA were amplified via PCR using spe-

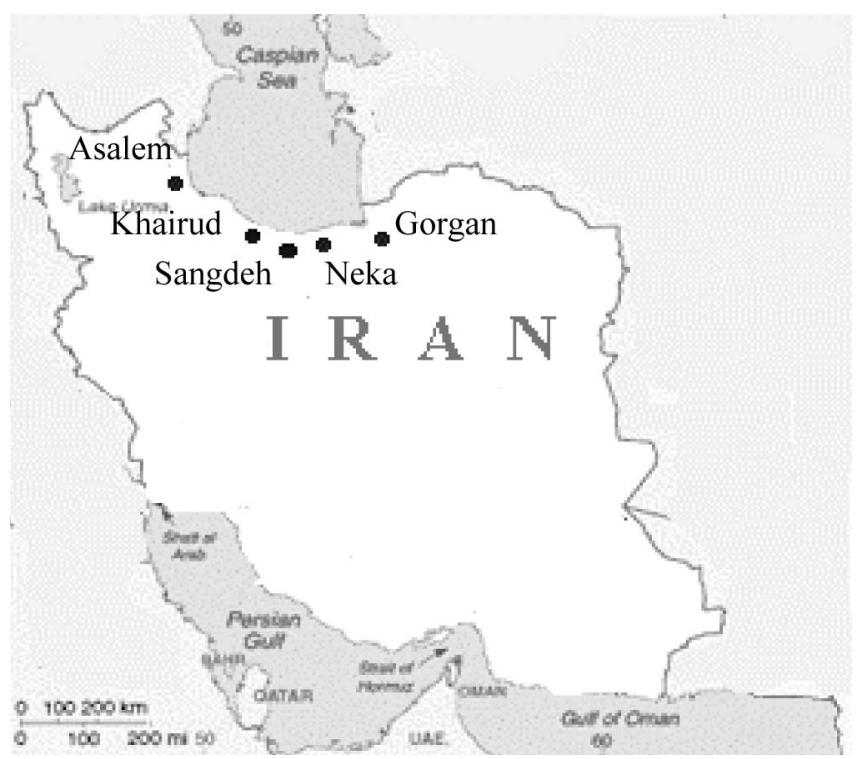

Figure 1. - Location of studied regions. cific pairs of chloroplast primers (Table 2). PCR reactions were carried out on a template of genomic DNA (10 ng for each reaction). The reaction mixture was composed by $10 \mathrm{mM}$ Tris- $\mathrm{HCl}$ ( $\mathrm{pH}$ 8.3), $50 \mathrm{mM} \mathrm{KCl}, 1.5 \mathrm{mM} \mathrm{MgCl}_{2}$ (Gibco BRL, Life Technologies), $0.001 \%(\mathrm{w} / \mathrm{v})$ gelatin, $250 \mu \mathrm{M}$ of each deoxynucleoside triphosphate (dNTP), $1 \mu \mathrm{M}$ of each Primer, $1 \mathrm{U}$ of Ampli Taq DNA polymerase (Perkin Elmer, USA) for a final volume of 20 pl. After incubation for $60 \mathrm{~s}$ at $90^{\circ} \mathrm{C}$, the reaction mixtures were subjected to different temperature profiles: (1) $95^{\circ} \mathrm{C}$ for $30 \mathrm{~s}, 60^{\circ} \mathrm{C}$ for $30 \mathrm{~s}, 72^{\circ} \mathrm{C}$ for $4 \mathrm{~min}$, for 5 cycles; (2) $95^{\circ} \mathrm{C}$ for $30 \mathrm{~s}, 55^{\circ} \mathrm{C}$ for $30 \mathrm{~s}, 72^{\circ} \mathrm{C}$ for $4 \mathrm{~min}$, for 5 cycles; and $(3) 95^{\circ} \mathrm{C}$ for $30 \mathrm{~s}, 50^{\circ} \mathrm{C}$ for $30 \mathrm{~s}, 72^{\circ} \mathrm{C}$ for $4 \mathrm{~min}$, for 25 cycles. Amplification products were then incubated at $72^{\circ} \mathrm{C}$ for $10 \mathrm{~min}$. (SAMBRoOK et al., 1989).

The DT and OA amplification products $(15 \mu l$ containing, $1 \mu \mathrm{g}$ of DNA) were treated with $5 \mathrm{U}$ of restriction enzyme Hae III and Hinf I (Takara, Japan), respectively, in a total volume of $20 \mu \mathrm{l}$ at $37^{\circ} \mathrm{C}$ for $4 \mathrm{~h}$ (Table 3). The mixtures ( $20 \mu \mathrm{l}$ per lane)

Table 2. - Details on primers used for the amplification of DT and OA cpDNA regions.

\begin{tabular}{clcc}
\hline Gene & Primer pairs and sequence & Code & Reference \\
\hline Trn D & ACCAATTGAACTACAATCCC & DT & Demesure et al., 1995 \\
$\operatorname{Trn} \mathrm{T}$ & CTACCACTGAGTTAAAAGGG & & \\
& & & \\
Orf184 & TGGCGATCAGAACATATATGGATAG & OA & Grivet et al., 2001 \\
petA & CCCTCGGAAACAAGAAGTT & & \\
\hline
\end{tabular}


Table 3. - Restriction endonuclease number individualized in DT and OA sequences in Nicotiana tabacum and Fagus sylvatica and number of restriction sited found in related intergenic spacer.

\begin{tabular}{lllcc}
\hline & & & \multicolumn{2}{c}{ Restriction site } \\
\cline { 1 - 2 } \cline { 5 - 5 } Endonuclease & Recognition sequence & & N. tabacum $^{2}$ & Fagus sylvatica $^{3}$ \\
\hline Hae III & $5^{\prime} \mathrm{GG} / \mathrm{CC}^{\prime}$ & & 3 & 2 \\
Hinf I & $5^{\prime} \mathrm{G} / \mathrm{AN}^{\prime} \mathrm{TC}^{\prime}$ & & 15 & 13 \\
\hline
\end{tabular}

${ }^{1} \mathrm{~N}=\mathrm{A}, \mathrm{C}, \mathrm{T}$ or $\mathrm{G}$

${ }^{2}$ Accession number: Z00044

${ }^{3}$ C. Vettori Personal Communication

were analysed by gel electrophoresis on $8 \%(\mathrm{w} / \mathrm{v})$ sequencing non-denaturing polyacrylamide gels (SAMBRook et al., 1989). The gels were poured and run in $1 \mathrm{x}$ TBE at a constant current of $166 \mathrm{~mA}$ for 9 hours and were stopped $2 \mathrm{~h}$ after the xilene cyanol FF (this dye co-migrates with the fragment of $160 \mathrm{bp}$ of double stranded DNA) reached the edge of the gel and completed gushed from the gel (S2001 Life Technologies).

The gels were stained with ethidium bromide and scanned (Photo-Capt, Vilbert Loormat, France). A 100 bp ladder from Genenco (Germany) was used as size marker.

\section{Statistical analysis}

Polymorphism was scored as point mutations or insertion/ deletions characters and used to define chloroplast haplotypes (according to different combination length variants).

Parameters of diversity $\left(h_{s}\right.$ and $\left.h_{t}\right)$ and differentiation $\left(G_{s t}\right.$ and $N_{s t}$ ) in the chloroplast genome were estimated following the methods described by Pons and Petit (1995, 1996) using the software HAPLODIV. $G_{s t}$ is based only on the haplotype frequencies, whereas $N_{s t}$ takes into consideration genetic similarities between haplotypes (proportion of shared fragments). These two parameters were compared (PONS and PETIT, 1996). The contribution of a given population to total diversity $\left(C_{t}\right)$ was calculated as reported by PETIT et al. (1997).

A ratio of seed flow to pollen flow was calculated using the equation of ENNOS (1994) in which $\mathrm{F}_{\mathrm{ST}}$ was substituted by $\mathrm{G}_{\mathrm{ST}}$ :

$$
\frac{\text { pollen flow }}{\text { seed flow }}=\frac{\left(\frac{1}{\text { Gstb }}-1\right)-2\left(\frac{1}{\text { Gstc }}-1\right)}{\left(\frac{1}{\text { Gstc }}-1\right)}
$$

Where $\mathrm{G}_{\mathrm{STb}}$ and $\mathrm{G}_{\mathrm{STc}}$ indicate the level of population subdivision based on nuclear and cytoplasmic markers respectively.

$G_{s t c}$ from this study was used as an estimator of population subdivision in maternally inherited genomes, whilst the value of $G_{s t b}$ for allozyme from $F_{s t}$ in SALEHI SHANJANI (2002).

\section{Results}

No differences in sizes of the DT and OA amplified products were found among Iranian populations with agarose gel electrophoresis. The digestion profiles of the two fragments were compared simultaneously with the digestion fragments of control DNA of known haplotype (kindly provided by R. GIANNINI, IGV Sec. CNR, Florence, Italy) to identify Iranian haplotypes. The restriction fragments of the region DT did not show polymorphism among individuals within any population analysed. However, among individuals within analysed populations of Asalem region and Neka-1400 population, polymorphism in the restriction fragments of the $\mathrm{OA}$ region were found. By the simultaneous comparison of the digestion profiles of the DT and $\mathrm{OA}$ fragments with the corresponding digestion fragments of Italian control DNA of known sequences and haplotypes, it has been possible to determine the $\mathrm{DT}$ and OA variants present in the Iranian populations. In the DT region, except the Kheirud-600 population, which had the polymorphic fragment, variant 4 , the same fragment of variant 1 was found in all the other populations of Hyrcanian forests. The length of polymorphic fragment analyses at OA region indicate that the variant 4 was present in one individual of Neka-1400 population, in two individuals of Asalem-1900 and Asalem-1200 populations, and in three individuals of Asalem-600 population, and the variant 3 in all the individuals of the other populations (Table $4,5)$.

On the other hand restriction analysis identified 2 variants for each region, which combine into $3 \mathrm{cpDNA}$ haplotypes. The distribution of the observed haplotypes in each population is reported in Table 5.

Most haplotypes differ from each other for one mutation event. The geographic distribution of the cpDNA haplotype (Hap) is Hap 2 with a frequency of 0.79 , and presents in all the natural range of Hyrcanian forests but one (Kheirud-600). One relatively rare haplotype with a frequency of 0.103 (Hap 3) is present at the level of single individual (indiv) in few populations of West Hyrcanian forests (Asalem-600, Asalem-1900 and Neka-1200) or in one population in Neka-1400 the Center of Hyrcanian). Hap 14 was peculiar of Kheirud-600 population (6 indiv). Most of the cpDNA differentiation is distributed among populations $\left(\mathrm{G}_{\mathrm{st}}=68.70 \%\right)$.

The total diversity $\left(h_{t}\right)$ was 0.364 . The Kheirud-600, Asalem 1900, Asalem 1200 and Asalem 600 populations, having a $C_{t}$ of $0.290,0.026,0.260$ and 0.027 , respectively, have contributed

Table 4. - Number of PCR-RFLP bands and type of variants detected in $\mathrm{DT}$ and OA regions of $F$. orientalis.

\begin{tabular}{ccccc}
\hline Primer code & $\begin{array}{c}\text { Total RFLP } \\
\text { bands }^{1}\end{array}$ & $\begin{array}{c}\text { Total number } \\
\text { of variants }^{2}\end{array}$ & $\begin{array}{c}\text { Code of each } \\
\text { variant }\end{array}$ & $\begin{array}{c}\text { Mutation type of each } \\
\text { variant }\end{array}$ \\
\hline DT & 3 & 2 & $1 \& 4$ & In/del ${ }^{3}$ \\
OA & 14 & 2 & $3 \& 4$ & In $/ \mathrm{del}$
\end{tabular}

${ }^{1}$ Indicates the total number of bands detected by electrophoresis after digestion of each amplified fragment.

${ }^{2}$ Indicates the number of electrophoretic variants detected for each single polymorphic band.

${ }^{3} \mathrm{In}=$ Insertion; del = deletion

Table 5. - Details on sample size, location, and number of individuals per haplotype and haplotype frequencies in F. orientalis populations.

\begin{tabular}{|c|c|c|c|c|c|c|c|c|c|}
\hline \multirow[b]{2}{*}{ Population } & \multicolumn{2}{|c|}{ Variation } & \multicolumn{3}{|c|}{ Haplotypes PCR-RFLP } & \multirow[t]{2}{*}{ Sample size } & \multicolumn{3}{|c|}{ Haplotype frequency } \\
\hline & DT & $\mathrm{OA}$ & $2^{*}$ & $3^{* *}$ & $14^{* * * *}$ & & $2^{*}$ & $3^{* *}$ & $14^{* * *}$ \\
\hline G-2000 & 1 & 3 & 5 & 0 & 0 & 5 & 1.0 & 0.0 & 0.0 \\
\hline G-1400 & 1 & 3 & 5 & 0 & 0 & 5 & 1.0 & 0.0 & 0.0 \\
\hline G-600 & 1 & 3 & 5 & 0 & 0 & 5 & 1.0 & 0.0 & 0.0 \\
\hline $\mathrm{N}-1400$ & 1 & 3,4 & 4 & 1 & 0 & 5 & 0.8 & 0.2 & 0.0 \\
\hline N-900 & 1 & 3 & 5 & 0 & 0 & 5 & 1.0 & 0.0 & 0.0 \\
\hline S-1900 & 1 & 3 & 5 & 0 & 0 & 5 & 1.0 & 0.0 & 0.0 \\
\hline S-1400 & 1 & 3 & 5 & 0 & 0 & 5 & 1.0 & 0.0 & 0.0 \\
\hline S-900 & 1 & 3 & 5 & 0 & 0 & 5 & 1.0 & 0.0 & 0.0 \\
\hline K-2000 & 1 & 3 & 5 & 0 & 0 & 5 & 1.0 & 0.0 & 0.0 \\
\hline K-1200 & 1 & 3 & 5 & 0 & 0 & 5 & 1.0 & 0.0 & 0.0 \\
\hline $\mathrm{K}-600$ & 4 & 3 & 0 & 0 & 6 & 6 & 0.0 & 0.0 & 1.0 \\
\hline A- 1900 & 1 & 3,4 & 3 & 2 & 0 & 5 & 0.6 & 0.4 & 0.0 \\
\hline A- 1200 & 1 & 3,4 & 3 & 2 & 0 & 5 & 0.6 & 0.4 & 0.0 \\
\hline A -600 & 1 & 3,4 & 3 & 3 & 0 & 6 & 0.5 & 0.5 & 0.0 \\
\hline Total & & & 58 & 8 & 6 & 72 & 0.79 & 0.102 & 0.08 \\
\hline
\end{tabular}

*: Most frequent haplotype in North of Europe and North of Italy +2 populations of Bulgaria

**: Most frequent haplotype in North of Europe and North of Italy +2 individuals of one population in Bulgaria

***: one population in Iran 
much more to the total diversity. In some populations intrapopulation polymorphism is also found (Neka-1400, Asalem-1900, Asalem-1200 and Asalem-600). According to these results one of the populations of Kheirud (as unique haplotype), and the Asalem region (the most polymorphic) are the most particular populations.

The $N_{s t}(70.3 \%)$ is similar to $\mathrm{G}_{\mathrm{st}}(68.7 \%)$ indicating that the haplotypes are phylogenetically equivalent [U test $\left(\mathrm{N}_{\mathrm{st}} / \mathrm{G}_{\mathrm{st}}\right)=$ $1.02]$, and that only a geographical structure is evident.

Results obtained from the application of ENNos's formula (pollen flow/seed flow ratio) indicated that interpopulation pollen flow is 44 times greater than interpopulation seed flow.

\section{Discussion}

We were able to recognize 3 distinct cpDNA haplotypes in $F$. orientalis. The PCR-RFLP haplotypes distribution showed that: i) the most common haplotype (2) is present in all but one population, ii) 10 of 14 populations are monomorphic (fixed haplotypes 2 and 14). These observations show that the genetic diversity of $F$. orientalis in Iran follows a geographic pattern.

Many studies have reported geographic pattern in cpDNA variation below the species level (MAYER et al., 1994; SEWELL et al., 1996; DUMOLIN-LAPÉGUE et al., 1997, 1998; VAN DiJK and BakX-Schatman, 1997; Wolf et al., 1997; King and FerRis, 1998; Tremblay and Schoen, 1990; Аввотt et al., 2000). Furthermore, intra-specific cpDNA variation has been observed among Fagus species including Fagus sylvatica (DEMESURE et al., 1996), F. crenata (FUJII et al., 2002). Results of most of these studies suggest that key historical events (e.g. glacial events) have profound effects on the geographic structure of cpDNA variation.

DEMESURE et al. (1996) investigated the cpDNA diversity and geographic structure of the European beech (Fagus sylvatica). In Northern Europe, widespread distribution of a single cpDNA haplotype was observed, on the other hand, many haplotypes were recognized in Southern Europe. Although clearcut variation in cpDNA distribution has been observed, no such clear-cut patterns have been observed by FUJII et al. (2002) in Japanese beech. In the present analysis, however, one haplotype (type 2) was widely distributed in the all studied populations except population Kheirud-600. The second frequent cpDNA haplotype (type 3 ) was found to be basically segregated between the western most and remind parts of Hyrcanian forests. It has been hypothesized that Hyrcanian forests were formed by environmental differences, especially in the amount of precipitation, air humidity, temperature, humus and bed rock kind from East to West (MARVIE-MOHADJER, 1976; PARSAPAJOUH, 1976; HABIBI, 1985). An alternative explanation is that the distribution pattern of $F$. orientalis cpDNA haplotypes may reflect migration history of beech during historical distribution in Tertiary from Asalem (most polymorphic region) to East of Hyrcanian forests.

Differences between Kheirud-600 and other populations of Iranian beech were evident from the cpDNA analysis. This population was also characterized by a high level of genetic variability from allozyme analysis, mainly because of abundant rare alleles (SALEHI-SHANJANI, 2002).

The level of population subdivision was higher for the other European Fagaceae investigated so far: $\mathrm{G}_{\mathrm{STc}}=0.902$ for Fagus sylvatica (DEMESURE et al., 1996), $\mathrm{G}_{\mathrm{STc}}=0.829$ for Quercus petraea, $\mathrm{G}_{\mathrm{STc}}=0.907$ for $Q$. pubescens, and $\mathrm{G}_{\mathrm{STc}}=0.782$ for Q. robur (DUMOLIN-LAPÉGUe et al., 1997). The only related Fagaceae of the southern hemisphere studied so far, Nothofagus nervosa, showed a very clear geographical pattern of
cpDNA polymorphism, revealing a geographical divide across its distribution area in Argentina (MARCHELLI et al., 1998).

Iranian beech dose not show a geographically structured distribution of the diversity using nuclear isozyme markers (SALEHI SHANJANI, 2002) but the level of cpDNA differentiation among populations in beech is not low $\left(\mathrm{G}_{\mathrm{STc}}=68.7 \%\right)$ : the most common haplotype (2) is widely dispersed in almost all distribution areas but haplotype 3 is distributed principally in the west of Hyrcanian forests.

Analysis of the cpDNA variation within species has demonstrated that the majority of the variation is located among populations, with very low levels of intrapopulation variation (Soltis et al., 1989, 1991; Kim et al., 1992; Ретіт et al., 1993a, b). In a comparative study of population subdivision measured for 97 plant species was $G_{\text {st }}=0.70$; in particular the $G_{\text {st }}$ value was 0.73 for angiosperm tree species. Species belonging to the family of Fagacea and producing heavy seeds, like F. sylvatica, Quercus robur and $Q$. petraea are characterized by higher values of $\mathrm{G}_{\mathrm{st}}$ ranging between $83 \%$ and $90 \%$ (DEMESURE et al., 1996; DuMOLIN-LAPÈGUe et al., 1997). Even for Alnus glutinosa, a species characterized by wind dispersal of tiny winged seeds, a high value of genetic differentiation estimated using chloroplast markers was reported $\left(\mathrm{G}_{\mathrm{st}}=87 \%\right.$, KING and FERRIS, 1998).

The pollen/seed flow value for Iranian beech is 44 . This value can be explained by wind-pollination in concordance with other species of Fagaceae (Quercus robur $=286, Q$. petraea $=500$ and F. sylvatica $=84$, Petit, 1999) but is in contrast with chestnut $(=1$, Fineschi et al., 2000), which maybe explained by the insect contribution to the pollination and the active role of humans in moving and transferring not only fruits but also propagation material. On the other hand, the pollen/seed flow ratio is low when calculated for tree species characterized either by insect pollination or by very efficient seed dispersal mechanisms (FINESCHI et al., 2000).

\section{References}

Аввотt, R. J., Smith, L. C., Milne, R. I., Crawford, R. M. M., WolfF, K. and BALFOUR, J. (2000): Molecular analysis of plant migration and refugia in the arctic. Science 286: 1343-1346.

ARnold, M. L., Buckner, C. M. and Robinson, L. (1991): Pollen-mediated introgression and hybrid speciation in Louisiana irises. Proc. Nati. Acad. Sci., USA. 88: 1398-1402.

Avise, J. C., Arnold, J., Ball, R. M., Bermigham, E., Lamb, T., Neigel, J. E., ReEB, C. A. and SAuners, N. C. (1987): Intraspecific phylogeography: the mitochondrial bridge between population genetics and systematics. Annual Review of Ecology and Systematics 18: 489-522.

Byrne, M. and Moran. G. F. (1994): Population divergence in the chloroplast genome of Eucalyptus nitens. Heredity 73: $18-28$.

Demesure, B., Comps, B. and Petit, R. J. (1996): Chloroplast DNA phylogeography of the European beech (Fagus sylvatica L.) in Europe. Evolution 50(6): 2515-2520.

Demesure, B., Sodzi, B. N. and Petit, R. J. (1995): A set of universal primers for amplification of polymorphic noncoding regions of mitochondrial and chloroplast DNA in plants. Molecular Ecology 4: 129-131.

Dumolin-Lapégue S., Demesure, B., Lecorre, V., Fineschi, S. and Petit, R. J. (1997): Phylogeographic structure of white oaks throughout the European continent. Genetics 146: 1475-1487.

Dumolin-Lapègue, S., Pemonge, M. H. and Petit, R. J. (1998): Association between chloroplast and mitochondrial lineage in oaks. Biol. Evol. 15: 1321-1331.

ENNos, R. A. (1994): Estimating the relative rates of pollen and seed migration among plant populations Heredity 80: $548-593$. 
Fineschi, S. Taurchini, F., Villani, F., and Vendramin, G. G. (2000): Chloroplast DNA polymorphism reveals little geographical structure in Castanea sativa Mill. (Fagaceae) throughout southern European countries. Molecular Ecology 9: $1495-1503$.

Fuji, N., Tomaru, N., Okuyama, K., Koike, T., Mikami, T., and UEDA, K. (2002): Chloroplast DNA phylogeography of Fagus Creneta (Fagaceae) in Japan. Plant Syst. Evol. 232(1-2): $21-33$.

Grivet, G., Heinze, B., Vendramin, G. G. and Petit, R. J. (2001): Genome walking with consensus primers: application to the large single copy region of chloroplast DNA. Molecular Ecology Notes 1.

HABIBI, H. (1985): Investigation on soil of beech forests in Iran and its role on development of different type of beech forests. Iranian Journal of Natural Resources 39: 6-18.

Kim, K. J., JANSEN, R. K. and TURNeR, B. L. (1992): Evolutionary implications of intraspecific chloroplast DNA variation in Dwarf Dandelions (Krigia, Asteracea). American Journal of Botany 79: 708-715.

KING, R. A. and FERRIS, C. (1998): Chloroplast phylogeography of Alnus glutinosa (L.) Gaertn. Molecular Ecology 7: $1151-1161$.

Marchelli, P., Gallo, L., Scholz, F. and Ziegenhagen, B (1998): Chloroplast DNA markers reveal a geographical divide across Argentinean southern beech Nothofagus nervosa (Phil.) Dim. et Mil. Distribution area. Theoretical and Applied Genetic 97: 642-646.

MARVIE-MoHADJER, M. R. (1976): Some quantitative characteristics of Iranian beech forests. Iranian Journal of Natural Resources 34: 77-97 (1976).

MaYer, M. S., Soltis, P. S., Soltis, D. E. (1994): The evolution of the Streptanyhus glandulosus complex (Cruciferae): genetic divergence and gene flow in serpentine endemics. Amer. J. Bot. 81: 1288-1299.

Mobayen, S. and Tregubov, V. (1969): The vegetative map of Iran. Publication of Tehran University 14: 50

PARSAPAJOUH, D. (1976): Research on physical characteristics of Iranian beech timbers in different growing stations. Iranian Journal of Natural Resources 34: 21-34.

Petit, R. J., Kremer, A. and Wagner, D. B. (1993a): Finite island model for organelle and nuclear genes in plants. Heredity 71: 630-641.

Petit, R., Kremer, A. and Wagner, D. B. (1993b): Geographic structure of chloroplasy DNA polymorphisms in European oaks. Theoretical and Appled Genetics 87: 122-128.

Petit, R. J., E1 Mousadik A. and Pons, O. (1997): Identifying populations for conservation on the basis of genetic markers. Conserv. Biol. 12: 844-855 (1997).

Petit, R. J. (1999): Diversité Génétique et Historie des Populations d'Arbres Forestiers. Dossier d'habilitaion à diriger des recherches, Université de Paris-Sud, Université Formation de Recherche Scientifique d’Orsay, Paris.
Pons, O. and PeTiT, R. J. (1995): Estimation, variance and optimal sampling of gene diversity. 1. Haploid locus. Theoretical and Applied Genetics 90: 462-470.

Pons, O. and Petit, R. J.: Measuring and testing genetic differentiation with ordered versus unordered alleles. Genetics 144: $1237-1245$.

SAGHeb-TALEBI, K. (2000): Hyrcanian forests (North of Iran), the unique Ecosystem in Near East region. XXI IUFRO Word Congress-Forests and Society: The Role of research, 7-12 August, Kuala Lumpur, Malaysia.

SAlehi Shanjani, P. (2002): Genetic diversity of Fagus oriental$i s \mathrm{~L}$. and its relationship with physiological, biochemical, and morphological characteristic of beech forests in Iran. Ph. D. dissertesion, Science Faculty, Teacing training University of Tehran, Iran.

SAmbrooK, J., Fritsch, E., F. and Maniatis, T. (1989): Molecular coloning: a laboratory Manual. Cold Spring Harbor Larbor Press, New York.

Sewell, M. M., Parks, C. R. and Chase, M. W. (1996): Interaspecific chloroplast DNA variation and biogeography of North American Liriodendron L. (Magnoliaceae). Evolution 50: $1147-1154$

Soltis, D. E., Soltis, P. S., Ranker, T. A. and Ness, B. D. (1989): Chloroplast DNA variation in a wild plant, Tolmiea menzii. Genetics 121: 819-826.

Soltis, D. E., Mayer, M. S., Soltis, P. S. and Edgerton, M. (1991): Chloroplast DNA variation in Tellima grandiflora (Saxifragaceae). American Journal of Botany 78: 1379-1390.

Soltis, D. E., Soltis, P. S. and Milligon, B. G. (1992): Intraspecific chloroplast DNA variation: systematic and phylogenetic implications. In: Soltis, P. S., Soltis, D. E. and Doyle, J. J. (Eds). Molecular Systematics of Plants. Chapman and Hall, New York. Pp.: 529.

Tarbelet, P., Fumagalli, L, Wust-Saucy, A.-G. and Cosson, J.F. (1998): Comparative phylogeography and post glacial colonization routes in Europe. Mol. Eco. 7: 453-464.

Tremblay, N. O. and Schoen, D. J. (1990): Molecular phylogeography of Dryas integrifolia: glacical refugia and postglacial recolonization. Molec. Ecol. 8: 1187-1198.

VAN DiJK, P. and BAKX-Schotman, T. (1997): Choroplast DNA phylogeography and cytotype geography in autopolyploid Plantago media. Molec. Ecol. 6: 345-352.

Whitemore, A. T. and SchaAl, B. A. (1991): Interspecific gene flow in sympatric oaks. Proc. Natl. Acad. Sci. 88: 2540-2544.

Wolf, P. G. Murray, R. A. and Sipes, S. D. (1997): Speciesindependent, geographical structuring of chloroplast DNA haplotypes in a montane herb Ipomopsis (Polemoniaceae). Molec. Ecol. 6: 283-291.

Wolfe, K. H., LI, W. H. and Sharp, P. M. (1987): Rates of Nucleotide substituation vary greatly among plant mitochondrial, chloroplat and Nuclear DNAs. Proc. Natl. Acad. Sci. 84: 9054-9058 (1987). 